\title{
PERANAN PENGAWASAN DALAM MENINGKATKAN EFEKTIVITAS KERJA KARYAWAN PADA CV. ANANDA PUTRA PALEMBANG
}

\author{
Oktariansyah *)
}

\begin{abstract}
ABSTRAK
Tujuan dari penelitian ini adalah untuk mengetahui bagaimana pengawasan yang dilakukan terhadap peningkatan efektivitas kerja karyawan pada CV. Ananda Putra Palembang. Metode yang digunakan dalam penelitian ini adalah metode deskriptif, kualitatif,yaitu penelitian dan metode pengumpulan data dengan mengamati secara langsung terhadap masalah yang telah diteliti, dengan tujuan agar masalah dapat diketahui dan dipahami. Hasil penelitian yang dilakukan penulis menunjukkan bahwa pengawasan dalam meningkatkan efektivitas kerja karyawan pada CV. Ananda Putra Palembang belum begitu di laksanakan.
\end{abstract}

Kata Kunci : Pengawasan, Efektifitas Kerja

\section{A. Latar Belakang}

Perusahaan sebagai salah satu organisasi yang mengelola faktor produksi seperti tanah, modal dan tenaga kerja, untuk menghasilkan barang dan jasa guna memperoleh pendapatan,. Dengan adanya faktorfaktor produksi yang di olah secara efisien, maka faktor-faktor produksi tersebut harus di rencanakan terlebih dahulu. Agar di dalam pelaksanaan dari pekerjaan itu sesuai dengan tujuan yang ingin dicapai dan rencana yang telah dibuat maka dibutuhkan pengawasan yang efektif.

Pengawasan merupakan salah satu fungsi manajemen yang penting dan perlu dilakukan pada setiap perusahaan, karena tanpa adanya pengawasan kemungkinan akan terjadinya penyelewengan, penyimpangan, atau pelaksanaan kegiatan yang dilakukan tidak sesuai dengan apa yang telah direncanakan.

Pelaksanaan fungsi pengawasan bertujuan untuk mengetahi apakah sesuatu berjalan sesuai dengan rencana yang telah digariskan dengan mengetahui kesulitan, kelemahan dalam bekerja, dan untuk mengetahui apakah segala sesuatu berjalan dengan efektif serta mencari jalan keluar bila dijumpai kesulitan-kesulitan atau kegagalan kearah perbaikan.
Untuk mendapatkan prinsip pengawasan yang efektif, maka perlu dipenuhi beberapa prinsip-prinsip pengawasan. Dua pokok yang merupakan suatu sistem pengawsan adanya rencana tertentu dengan pemberian instruksi serta wewenang kepada bawahan .prinsip pokok yang utama merupakan suatu keharusan, karena rencana tersebut merupakan garis-garis besar yang harus dilaksanakan oleh bawahan.

Jadi peranan pengawasan sangat penting dalam suatu perusahaan. Untuk mencapai suatu pengawasan yang baik didalam perusahaan sangat tergantung pengawasan yang dilaksanakan. Dalam hal ini pimipinan harus bisa menetapkan perencanaan, merancang sistem umpan balik informasi, membandinkan hasil sesungguhnya dengan standar yang terlebih dahulu ditetapkan, mengevaluasi, mengukur sejauh mana kemampuan pelaksaan operasional organisasi dalam mencapai tujuan, apakah sesuai dengan perencanaan, jika terjadi penyimpangan segera diambil tindakan perbaikan.

Dalam hal ini penulis mengambil objek penelitian pada CV. Ananda Putra Palembang yang merupakan salah satu perusahaan jasa yang 
bergerak dibidang kontraktor, perdagangan umum, pengangkutan, perencanaan,

pelaksanaan/pemborongan jalan, yang tidak

terlepas dari peran aktif tenaga kerja atau karyawan yang memilliki kemampuan, kreativitas, inovatif dan bertanggung jawab dalam melaksanakan pekerjaannya berupaya mewujudkan sistem dan iklim yang baik.

Berdasarkan pengamatan yang penulis lakukan bahwa pimpinan perusahaan CV. Ananda Putra Palembang, pengawasannya belum dilaksanakan dengan efektif, karena kurangnya disiplin kerja karyawan, antara lain tingkat absensi, jam kerja dan pulang karyawan. karena pimpinan dan kepala bagian belum melaksanakan pengawasan dengan baik dan efektif. Pelaksanaan pengawasan hanya dilakukan setelah terjadinya penyimpangan karena pengawasan dilakukan secara tidak langsung dalam arti pengawasan itu dilakukan dengan menerima laporanlaporan dari bawahanya dalam bentuk tertulis. Dalam hal ini pimpinan tanpa menandatangi atau melihat tempattempat pelaksanaan dari suatu pekerjaan atau objek yang sedang diawasi akibatnya penyimpangan sering terjadi di dalam pelaksanaan tugas-tugas pekerjaan yang dibebankan kepada karyawan. Hal ini berarti bahwa dalam melaksanakan pengawasan perusahaan belum dapat mencapai efektivitas yang memuaskan sehingga hal ini menjadi suatu masalah bagi perusahaan.

\section{B. Rumusan Masalah}

Berdasarkan latar belakang dan identifikasi masalah serta batasan masalah diatas maka dapat dirumuskan bahwa bagaimana pengawasan dalam meningkatkan efektivitas kerja karyawan pada CV. Ananda Putra Palembang.

\section{Metode Penelitian}

Metode penulisan yang dilakukan penulis adalah bersifat deskriptif kualitatif yaitu penulis berusaha mengungkapkan suatu masalah dalam keadaan sebagaimana mestinya, serta menguraikan masalah.

\section{E. Operasional Variabel}

Operasional Variable adalah definisi yang diberikan kepada suatu variable dengan cara memberikan arti yang diperlukan untuk mengukur variable tersebut, (Arikunto 1998 : 99) Pengertian Pengawasan merupakan fungsi akhir yang harus dilaksanakan dalam manajemen. Dengan pengawasan dapat diketahui tentang hasil yang telah dicapai. Cara yang dilakukan dalam pengawasan yaitu membandingkan segala sesuatu yang telah dijalankan dengan standar atau rencananya, serta melakukan perbaikan-perbaikan bila terjadi penyimpangan. Jadi dengan pengawasan dapat mengukur seberapa jauh hasil yang telah dicapai sesuai dengan apa yang telah direncanakan. Dengan demikian pengawasan merupakan langkah ke arah pelaksanaan rencana yang telah disusun sebelumnya. Untuk memahami fungsi pengawasan, maka akan dikemukakan oleh penulis beberapa definisi dari pada pengawasan menurut para ahli.

\section{F. Teknik Pengumpulan Data}

1. Data primer adalah data yang didapat langsung dari objek penelitian dalam hal ini dapat menjadi objek penelitian adalah $\mathrm{CV}$. Ananda Putra Palembang.

a. Observasi

Penulis melakukan pengamatan secara langsung ke lokasi 
penelitian.

b. Wawancara

Penulis mengadakan tanya jawab langsung dengan pihak intern perusahaan (bagian SDM) guna mendapatkan gambaran yang jelas mengenai kegiatan yang dilakukan perusahaan yang berhubungan dengan masalah yang diteliti.

c. Kuisioner

Yaitu dengan mengajukan daftar pertanyaan yang sudah disusun untuk responden sedangkan untuk mengukur variabel-variabel dalam penelitian ini digunakan skor untuk setiap jawaban dari setiap pertanyaan.

2. Data Sekunder

Data sekunder adalah pengumpulan data dengan mempelajari masalah-masalah yang berhubungan dengan objek yang diteliti melalui buku pedoman literature yang disusun para ahli yang berhubungan dengan masalah yang dibahas.

\section{G. Populasi dan Sampel}

Populasi dalam penelitian ini adalah semua karyawan sub bagian Sumber Daya Manusia berjumlah 10 orang. Menurut Arikunto tentang sampel dalam bukunya berjudul Manajemen Pengajaran Kerja Secara Manusiawi (1993;104) adalah sebagian akan waktu dan subjek yang akan diteliti.

Sampel yang akan diteliti, mengacu pada pendapat Suharsimi Arikunto (1973:109) yaitu apabila subjek kurang dari 100 sebaiknya diambil semua sehingga penelitiannya merupakan penelitian populasi, jika jumlah subjek lebih dari 100 dapat diambil $10-15 \%$ atau $20 \%-25 \%$ atau lebih tergantung setidak-tidaknya dari kemampuan peneliti dilihat dari segi waktu dan lamanya. Luasnya wilayah pengamatan dari setiap subjek karena hal ini menyangkut banyak sedikitnya jasa. Berdasarkan pendapat tersebut diatas, penulis mengambil semua dari populasi yang ada sebanyak 10 orang karyawan sebagai sampel penelitian ini.

\section{Contoh:}

Tabel pengambilan sampel karyawan sub bagian Sumber Daya manusia

\begin{tabular}{|c|l|c|c|}
\hline No & \multicolumn{1}{|c|}{ Jabatan } & $\begin{array}{c}\text { Jumlah } \\
\text { pegawai }\end{array}$ & $\begin{array}{c}\text { Sampel } \\
\text { penelitian } \\
100 \%\end{array}$ \\
\hline 1 & Kabag SDM & 1 & 1 \\
\hline 3 & Kaur SDM & 1 & 1 \\
\hline 4 & Kabag ADM & 1 & 1 \\
\hline 5 & Kaur ADM & 1 & 1 \\
\hline 6 & Staf-staf & 6 & 7 \\
\hline & Jumlah & 10 & 10 \\
& & $(100 \%)$ \\
\hline
\end{tabular}

Sumber : CV. Ananda Putra Palembang

\section{H. Pembahasan}

Pada bab analisa ini sesuai dengan data yang penulis kemukakan pada bab terdahulu dan berdasarkan permasalahan yang dihadapi oleh $\mathrm{CV}$. Ananda Putra Palembang, maka penulis membahas atau menganalisa permasalahan tersebut dengan membandingkan teori-teori yang ada.

\section{Peningkatan Pengawasan dalam Meningkatkan Efektivitas Kerja Karyawan CV. Ananda Putra Palembang}

Berdasarkan pengamatan

penulis bahwa pimpinan perusahaan CV. Ananda Putra Palembang, pengawasan belum dilaksanakan dengan efektif, karena kurangnya disiplin kerja karyawan, antara lain tingkat absensi, jam kerja dan jam pulang karyawan, karena pimpinan dan kepala bagian belum melaksanakan pengawasan dengan baik dan efektif, pelaksanaan pengawasan hanya dilakukan setelah terjadinya penyimpangan karena pengawasan dilakukan secara tidak 
langsung dalam arti pengawasan itu dilakukan dengan menerima laporanlaporan dari bawahanya dalam bentuk tertulis. Dalam hal ini pimpinan tanpa mendatangi atau melihat tempattempat pelaksanaan dari suatu pekerjaan atau objek yang sedang di awasi akibatnya penyimpangan sering terjadi didalam pelaksanaan tugastugasnya yang dibebankan kepada karyawan. Hal ini berarti bahwa dalam melaksanakan pengawasan perusahaan belum dapat tercapai efektivitas yang memuaskan sehingga hal ini menjadi suatu masalah bagi perusahaan.

Pengawasan pada hakekatnya merupakan usaha memberikan petunjuk kepada para pelaksana agar mereka bertindak sesuai dengan rencana. Pengawasan merupakan salah satu pengawasan pada perusahaan ini,fungsi manajemen terdiri dari. Pengawasan langsung dan tidak langsung. Pengawasan langsung adalah pengawasan yang dilakukan pimpinan suatu organisasi dalam melakukan pemeriksaan langsung pada tempat pelaksanaan pekerjaannya baik dengan sistem verifikasi maupun sistem investigasi dengan melakukan pengawasan terhadap pegawai /karyawan dengan pengawasan secara tidak langsung adalah dengan melihat laporanlaporan yang berkaitan dengan kedisiplinan dan keaktifan pegawai dalam melaksanakan kewajibannya, misalnya untuk melihat keaktifan dan kedisiplinan karyawan kepada seksi Sumber Daya Manusia bisa melihat dari daftar hadir dan rekapitulasi.

Sebagaimana diketahui disiplin adalah salah satu pembinaan semangat atau moril kerja pegawai dalam menjalankan tugasnya, supaya tertib, berdaya guna dan berhasil guna.untuk meningkatkan efektivitas kerja karyawan seksi sumber daya manusia CV. Ananda Putra Palembang perlu meningkatkan pengawasan sebagai berikut :

1. Absensi kehadiran yang dilakukan pada setiap hari kerja pada unit satuan kerja masing-masing.

2. Adanya rekapitulasi absensi karyawan.

3. Daftar hadir dan rekapitulasi dilanjutkan ke Kepala Urusan Administrasi setelah itu diberikan kepada Kepala Bagian Administrasi CV. Ananda Putra Palembang untuk diserahkan ke Kepala Bagian SDM CV. Ananda Putra Palembang.

Kepala Bagian Sumber Daya Manusia selalu memberikan pengarahan tentang disiplin agar setiap karyawan ditanamkan rasa memiliki terhadap perkerjaanya, Kepala Seksi Sumber daya manusia selalu menegaskan kepada bawahannya, mau dibawa kemana CV. Ananda Putra Palembang maju atau mundur semuanya tergantung dari Sumber Daya Manusia nya. Bila Sumber Daya Manusia nya sudah menanamkan rasa disiplin, baik jam kerja maupun dalam menjalankan tugas-tugas yang diberikan oleh pimpinan maka keberhasilan suatu tujuan akan tercapai demikian juga sebaliknya.

4. Pengambilan tabel jam kerja karyawan CV. Ananda Putra Palembang.

Jam kerja yang berlaku pada CV. Ananda Putra Palembang sesuai dengan peraturan yang dikeluarkan oleh Kepala Urusan Administrasi dimana jam kerja tersebut: 


\begin{tabular}{|c|c|c|}
\hline $\begin{array}{c}\text { Hari } \\
\text { kerja }\end{array}$ & $\begin{array}{c}\text { Masuk } \\
\text { kerja }\end{array}$ & $\begin{array}{c}\text { Pulang } \\
\text { kerja }\end{array}$ \\
\hline Senin & 08.00 & 16.00 \\
Selasa & 08.00 & 16.00 \\
Rabu & 08.00 & 16.00 \\
Kamis & 08.00 & 16.00 \\
Jum'at & 08.00 & 16.00 \\
\hline \multicolumn{2}{|c|}{ Sumber: }
\end{tabular}

Sumber: Ananda Putra Palembang

Hari kerja yang berlaku di CV. Ananda Putra Palembang yaitu 5 hari kerja sementara hari Sabtu libur sesuai dengan ketentuan pemerintah tentang ketenagakerjaan. Sesuai dengan bab terdahulu jam kerja, masuk karyawan dan pulang bervariasi, hal ini disebabkan adanya alasan seperti jarak dari rumah ke kantor jauh, alasan keluarga, jalan macet, kendaraan sulit. Pelanggaran atas disiplin pegawai, Kepala Bagian Sumber Daya Manusia memberikan tingkat hukuman sebagai berikut:

1. Hukuman disiplin ringan.
a. Teguran lisan.
b. Teguran tertulis.
c. Pernyataan tidak puas secara tertulis.

2. Hukuman disiplin sedang

a. Penundaan kenaikan gaji berkala paling lambat satu tahun.

b. Penurunan gaji sebesar satu kali kenaikan gaji berkala untuk paling lama satu tahun.

c. Penundaan kenaikan pangkat untuk paling lama satu tahun.

3. Hukuman disiplin berat
a. Penurunan pangkat pada
pangkat yang setingkat lebih rendah paling lama satu tahun.
b. Pembebasan dari jabatan.
c. Pemberhentian dengan hormat tidak atas permintaan sendiri.

d. Pemberhentian dengan tidak hormat.

Namun sejauh ini hukuman yang pernah dilakukan terhadap CV. Ananda Putra Palembang yaitu teguran secara lisan.

Teguran lisan terbagi dalam beberapa tingkatan seperti: teguran lisan pertama, bila teguran pertama tidak diindahkan maka diberikan teguran kedua, apabila teguran ini masih dilakukan oleh pegawai maka tindakan selanjutnya adalah dengan memberikan teguran tertulis.

Teguran tertulis ini juga diperingatkan sampai tiga kali. Pendisiplinan seperti ini merupakan jenis hukuman disiplin kolektif. Berdasarkan teori T. Hani Handoko (2001:209) yaitu kegiatan yang diambil untuk menangani pelanggaran terhadap aturanaturan dan mencoba untuk menghindari pelanggaranpelanggaran lebih lanjut.
1. Untuk
memperbaiki pelanggaran terhadap
peraturan yang telah
ditetapkan dalam perusahaan.
2. Untuk menghalangi para karyawan yang lain melakukan kesalahan yang serupa.

3. Untuk menjaga berbagai standar kelompok tetap konsisten dan efektif.

Rata-rata manusia tidak menyukai kerja dan akan menghindarinya jika mungkin, karena sifat manusia tidak menyukai kerja, tapi ingin mendapatkan hasil yang besar. Sebagian orang harus dipaksa dikendalikan, diarahkan dan diancam dengan hukuman untuk 
membuat mereka supaya berusaha. Menghadapi manusia seperti ini memang sulit karena pimpinan harus banyak berperan aktif untuk mengawasi bawahannya.

Orang yang memiliki sifat seperti ini cocok diberikan motivasi atau dorongan yang bersifat ancaman atau hukuman, dengan demikian mereka akan merasa takut untuk tidak mengerjakan tugas yang dibebankan kepadanya dan merasa diawasi terus menerus

Untuk itu pimpinan perlu
mengadakan usaha untuk
meningkatkan efektivitas kerja dan menerapkannya dengan baik. Namun untuk mendapatkan efektivitas kerja yang baik unsur pimpinan CV. Ananda Putra Palembang menciptakan suasana kerja yang dapat meningkatkan kerja sama dalam menjalankan tugas kantor, sehingga beban tugas tidak dirasakan sebagai suatu beban yang berat, akan tetapi merupakan kewajiban yang harus dilaksanakan dengan penuh rasa tanggung jawab.

Yang perlu diperhatikan oleh pimpinan dalam melaksanakan disiplin kerja adalah masuk atau pulang kerja tepat pada waktunya, kepada bawahan bersifat membimbing serta mengarahkan.

Dengan pemberian hukuman karyawan merasa takut, apabila tidak mentaati disiplin jam kerja. Diharapkan karyawan tidak melakukan kebiasaan datang terlambat ke kantor.

\section{Upaya Untuk Meningkatkan Efektivitas Kerja}

Untuk mengatasi hambatanhambatan tersebut maka diadakan upaya-upaya untuk mengatasinya yaitu :

1. Menetapkan

standar pelaksanaan atau perencanaan. Perencanaan harus ditetapkan terlebih dahulu agar tidak terjadi penyimpangan-penyimpangan dari fungsi pengawasan sehingga tujuan daripada organisasi dapat dilaksanakan sesuai rencana sebelumnya.

2. Penentuan pengukuran pelaksanaan kegiatan.

3. Pengukuran pelaksanaan kegiatan nyata.

4. Pembandingan pelaksana kegiatan dengan standar dan penganalisaan penyimpanganpenyimpangan.

5. Pengambilan tindakan koreksi bila perlu.

Dengan demikian hasil kerja dapat sesuai dengan rencana. Jika dihubungkan dengan perusahaan CV. Ananda Putra Palembang tampak bahwa pelaksanaan pengawasan dilaksanakan sendiri oleh pimpinan, sedangkan sebagaimana kita ketahui seorang pimpinan itu masih mempunyai kesibukan-kesibukan lain sehingga pengawasan disini hanya dilakukan secara sempit saja yaitu membandingkan rencana yang telah dibuat dengan hasil yang dicapai.

Setelah itu jika terdapat penyimpangan dengan kata lain hasil yang dicapai lebih kecil dari yang ditargetkan maka perlu diambil tindakan perbaikan agar setiap rencana untuk masa yang akan datang dapat dilaksanakan lebih efektif.

Dengan adanya pengawasan yang efektif, maka kesalahan, penyimpangan, pemborosan dan penyelewengan 
yang tidak sesuai dengan tugas dan wewenang yang telah ditetukan dapat dicegah atau diperbaiki, sehingga kemungkinan timbulnya kerugian yang besar dapat dhindari atau setidaktidaknya dapat diperkecil dan akhirnya dapat menimbulkan keuntungan bagi perusahaan. Penempatan orang-orang yang sesuai dengan bidangnya dan kemampuannya adalah sangat perlu sekali karena dengan menempatkan orang-orang yang tepat pada bidang yang sesuai dengan kemampuannya akan sangat berperan bagi kelanjutan usaha dalam suatu perusahaan.

Dengan adanya pembagian

kerja bagi setiap orang tersebut maka akan timbul pula tanggung jawab yang harus dipikul sesuai dengan beban dan tugas masingmasing. Kelancaran kerja dan semangat kerja yang tinggi akan timbul sehingga pencapaian tujuan dan sasaran-sasaran perusahaan diharapkan akan dapat dicapai sesuai dengan rencana.

Jelas kiranya bahwa dari uraian di atas bahwa tindakan yang dilakukan itu tidak serta merta dapat menyesuaikan pekerjaan yang kenyataannya dengan rencana atau standar. Oleh karena itulah, perlu sekali diadakannya laporan berkala sebagai bahan evaluasi perusahaan untuk mendeteksi kemungkinan kemajuan dan atau terdapat penyimpanganpenyimpangan. Setiap indikasi bila terjadi penyimpangan maka segera dilakukan perbaikan dalam jangka waktu yang sesingkat mungkin guna mengurangi atau memperkecil resiko yang akan terjadi akibat penyimpangan selanjutnya.
Berdasarkan data yang telah diuraikan, maka penulis akan memberikan beberapa kesimpulan dan saran-saran sebagai alternatif untuk pengembangan sistem pengawasan dalam perusahaan CV. Ananda Putra Palembang.

\section{Kesimpulan dan Saran}

1. Kesimpulan

Adapun kesimpulan yang dapat penulis rumuskan adalah sebagai berikut :

a. Belum adanya pengawasan secara efektif dalam meningkatkan efektivitas kerja karyawan seperti kurangnya disiplin kerja. Dalam kegiatan manajemen dalam suatu perusahaan sangat diperlukan adanya fungsi pengawasan yang efektif, karena fungsi pengawasan merupakan salah satu kegiatan dari pada pimpinan dalam melaksanakan organisasi, guna mencegah terjadinya kekeliruan, kesalahan dan penyelewengan terhadap segala peraturan, sehingga pencapaian tujuan dan sasaran-sasaran perusahaan diharapkan dapat dicapai sesuai dengan rencana.

b. Untuk dapat terwujudnya pelaksanaan kerja dengan baik dalam usaha meningkatkan efektivitas kerja, maka faktor manusia perlu diperhatikan karena manusia merupakan faktor yang paling penting dalam menentukan berhasil atau tidaknya melaksanakan tugas dan tanggung jawab yang dibeban kepada mereka dengan sebaik-baiknya.

c. Pengawasan yang dilakukan terhadap pelaksanaan fungsi pengawasan yang bersifat 
langsung kurang dilakukan pimpinan, jadi tidak menutup kemungkinan bawahan atau karyawan akan menyimpang dari standar atau rencana yang telah dibuat.

\section{Saran}

Berdasarkan kesimpulan di atas, maka penulis mencoba memberikan saran-saran yang dapat digunakan sebagai bahan pikiran dalam memajukan usaha pada masa yang akan datang.

Adapun saran-saran yang dapat penulis kemukakan sebagai berikut:

1. Proses pengawasan dengan mempergunakan peralatanperalatan manajemen, perlu di kembangkan dalam perusahaan yaitu penentuan standar, pengukuran kerja, dan membandingkan dengan standar serta mengambil tindakan untuk melakukan perbaikan bila dianggap perlu, dan meninggalkan sikap yang menganggap bahwa pengawasan keseluruhan dapat dilakukan dengan cara pengawasan langsung oleh manajer puncak saja, tetapi semua karyawan harus terlibat juga dalam melakukan pengawasan meningkatkan kompleksitas organisasi yang akan berpengaruh terhadap efektivitas kerja karyawan itu sendiri dalam mencapai tujuan yang sesuai dengan rencana yang telah disepakati bersama.

2. Untuk lebih meningkatkan efektivitas kerja, hendaknya seorang pimpinan harus lebih memperhatikan pengetahuan, keterampilan dan pengembangan kemampuan bagi karyawan. Caranya dengan mengadakan pendidikan dan pembinaan sehingga karyawan tersebut akan lebih menyadari terhadap tugas dan tanggung jawab yang di bebankan kepadanya agar pengawasan dapat berjalan dengan efektif disarankan agar orang yang di tugaskan adalah orang yang mengetahui arti, proses dan fungsi pengawasan, serta adanya pembagian kerja agar timbul rasa tanggung jawab masing-masing karyawan.

3. Dalam melaksanakan pengawasan dengan menggunakan laporan tertulis, supaya ditentukan secara pasti jangka waktu penyerahan laporan tersebut sehingga karyawan akan mempersiapkan laporan, jauh sebelum jangka waktunya dengan sesingkat mungkin guna mengurangi atau memperkecil resiko yang akan terjadi akibat penyimpangan selanjutnya.

\section{DAFTAR PUSTAKA}

Arikunto. $1998 . \quad$ Manajemen Pengajaran Kerja Secara Manusiawi. Edisi Revisi. Jakarta. Bumi Aksara.

Tani Handoko. 1998. Manajemen. Edisi ke 2 BPFE Yogyakarta.

Hasibuan.SP.Malayu.2005.Organisasi dan Motivasi,.Edisi revisi Penerbit Jakarta. Bumi Aksara.

Manulang. $1996 . \quad$ Dasar-dasar Manajemen, Ghalia Indonesia. Jakarta

Sarwoto. $1998 . \quad$ Dasar-dasar Organisasi dan Manajemen. Jakarta. Ghalia Indonesia.

Sigian P Sondang. 2005. Fungsi-fungsi Manajerial. Cetakan pertama edisi revisi. Jakarta. Bumi Aksara. 
Stoner, A.F, James. 1997. Manajemen, Edisi ke-2 Jakarta. Erlangga.

Sugiono.2003.Metodelogi Penelitan Administrasi.Penerbit.ALFABETA

Suwarno, Hadayaninggrat. 1996. IImu Administrasi dan Manajemen. Jakarta. Gunung Agung.

Terry.R.G.Prinsip Manajemen.Bumi Aksara.Jakarta.1998

Winardi. 1996. Asas-asas Manajemen. Mander Maju. Bandung. 